\title{
The use of bed sediments in water quality studies and monitoring programs
}

\author{
Arthur J. Horowitz ${ }^{1,2, *}$ and Kent A. Elrick ${ }^{1, *}$ \\ ${ }^{1}$ U.S. Geological Survey, Norcross, Georgia, 30093, USA \\ ${ }^{2}$ Dept. of Geosciences, Georgia State University, Atlanta, Georgia, 30303, USA \\ * retired
}

Correspondence to: Arthur J. Horowitz (horowitz1@ mindspring.com)

Published: 3 March 2017

\begin{abstract}
In most water quality monitoring programs, either filtered water (dissolved) or suspended sediment (either whole water or separated suspended sediment) are the traditional sample media of choice. This results both from regulatory requirements and a desire to maintain consistency with long-standing data collection procedures. Despite the fact that both bed sediments and/or flood plain deposits have been used to identify substantial water quality issues, they rarely are used in traditional water quality monitoring programs. The usual rationale is that bed sediment chemistry does not provide the temporal immediacy that can be obtained using more traditional sample media (e.g., suspended sediment, water). However, despite the issue of temporal immediacy, bed sediments can be used to address/identify certain types of water quality problems and could be employed more frequently for that purpose. Examples where bed sediments could be used include: (1) identifying potential long-term monitoring sites/water quality "hot spots", (2) establishing a water quality/geochemical history for a particular site/area, and (3) as a surrogate for establishing mean/median chemical values for suspended sediment.
\end{abstract}

\section{Introduction}

In typical environmental/water quality-monitoring programs the most common samples collected and analyzed are filtered and unfiltered (whole) water (e.g., ASTM, 2011a, b; APHA, 2012; Horowitz, 2013; USGS, various). The former are used to determine "dissolved" constituents whereas the latter are used to determine suspended sediment concentrations (SSCs)/grain-size distributions, and sedimentassociated chemical constituents by subtraction. Although bed sediments have been used in large-scale (e.g., national) environmental surveys, as well as for geochemical reconnaissance (e.g., mineral exploration), they rarely are used in traditional water quality-monitoring programs (e.g., Hawkes and Webb, 1962; Webb et al., 1978; Fauth et al., 1985; Otteson et al., 2000; Gustavsson et al., 2001). However, of all the potential sample media, bed sediments probably are the easiest to collect and process, and are least likely to suffer from contamination or insufficient sample mass/analytical detection issues. Hence, their lack of use is somewhat surpris- ing, but results from several factors. First, since the publication of the Hawkes and Webb (1962) treatise on geochemical exploration, as well as the publication of several national geochemical/environmental atlases (e.g., Webb et al., 1978; Fauth et al., 1985; Otteson et al., 2000), bed sediments have been used to detect geochemical/environmental spatial differences, but rarely are viewed as sensitive to short-term (geo)chemical variations; whereas the latter are the usual goal of most monitoring programs. Second, bed sediment surveys typically employ grain-size limited aliquots (e.g., $<180 \mu \mathrm{m})$ to facilitate spatial comparisons. That traditional grain-size range has little connection with suspended sediment grain-size distributions; hence, bed sediments have never been viewed as surrogates for suspended sediment. However, recent surveys using the $<63 \mu \mathrm{m}$ fraction of the upper $1 \mathrm{~cm}$ of bed sediments, collected after low-flow periods (e.g., Horowitz et al., 1999, 2001a, b, 2012, 2014), or surficial bed sediments collected from exposed surfaces after storms or floods (e.g., Van Metre et al., 2006; Horowitz et al., 2014), do appear to reasonably reflect suspended sed- 
Table 1. Summary of Utoy Creek data from the $<63 \mu \mathrm{m}$ fraction of bed sediment samples $(n=47)$.

\begin{tabular}{lrrrrrr|rrrrr}
\hline \multirow{2}{*}{ Units } & \multicolumn{7}{c|}{$\left(\mathrm{mg} \mathrm{kg}^{-1}\right)$} & \multicolumn{4}{c}{ (wt \%) } \\
\cline { 2 - 11 } Category & $\mathrm{Cu}$ & $\mathrm{Co}$ & $\mathrm{Ag}$ & $\mathrm{Cd}$ & $\mathrm{Pb}$ & $\mathrm{Zn}$ & $\mathrm{Al}$ & $\mathrm{Fe}$ & $\mathrm{Ti}$ & $\mathrm{TOC}$ \\
\hline Min & 16 & 16 & $<0.5$ & $<0.5$ & 38 & 100 & 9.3 & 2.8 & 0.55 & 1.4 \\
Max & 120 & 35 & 0.88 & 0.88 & 200 & 910 & 12.6 & 6.7 & 0.9 & 5.1 \\
Median & 56.5 & 22 & 0.61 & 0.35 & 80 & 220 & 10.5 & 4.7 & 0.68 & 2.8 \\
\hline Baseline (min)* & 14 & 8 & 0.1 & 0.2 & 14 & 71 & 4.9 & 2.2 & 0.25 & 1.3 \\
Baseline (max)* & 26 & 16 & 0.3 & 0.6 & 26 & 110 & 6.9 & 3.6 & 0.41 & 2.5 \\
\hline
\end{tabular}

* From Horowitz and Stephens (2008)

iment chemical composition. Hence, grain-size limited bed sediment aliquots may represent a useful media for nontraditional monitoring programs intended to detect eventrelated effects, or long-term environmental/water qualitychanges (e.g., decadal climate/land use-changes), provided samples are collected and analyzed every 5 to 10 years, or to determine mean/median suspended sediment associated chemical concentrations as a means of establishing first order approximations of fluvial fluxes of suspended sedimentassociated chemical constituents (e.g., Horowitz et al., 2012, 2014). Additionally, the chemical analysis of cored bed sediment samples, in conjunction with absolute age dating, can be used to reconstruct the water quality/geochemical history of an impoundment (e.g., Horowitz et al., 1988, 1995; Grosbois et al., 2001; Van Metre and Horowitz, 2013; Gray et al., 2015). Three examples of water quality studies that employed bed sediments in lieu of more traditional sample media, as a proof of concept, are described herein.

\section{Utoy Creek, Atlanta, Georgia}

Utoy Creek is a small urban stream that flows through the City of Atlanta, Georgia as well as well as being a tributary of the Chattahoochee River (e.g., Horowitz and Hughes, 2006; Horowitz, 2009; West Atlanta Watershed Alliance, 2016). The creek is some $42 \mathrm{~km}$ long and the watershed encompasses some $89 \mathrm{~km}^{2}$ (West Atlanta Watershed Alliance, 2016). In 2015 representatives from Fulton County contacted the authors with a request to evaluate water quality in the watershed with a view to identifying potential contaminants and to recommend long-term monitoring sites. The creek already had been listed as impaired as a result of elevated dissolved Zn levels (Andrew Mycroft, personal communication, 2015).

\subsection{Methods}

Bed sediment samples were manually collected during a week in late 2014 after an extended period of low-flow at roughly equidistant intervals covering the entire watershed; additionally, major tributaries to Utoy Creek also were sampled. Sampling procedures were similar to those used by
Horowitz et al. (2012) and entailed collecting multiple equal volume aliquots collected from the upper $1 \mathrm{~cm}$ of the creek bed and/or the still wet floodplain at each site. The aliquots for each site were composited in the field, stored in clear plastic bags, and refrigerated until they could be returned to the laboratory. In total, 47 samples were collected, of which 5 were replicates to evaluate sampling precision.

All the samples were processed and analyzed following the procedures outlined in Horowitz et al. (2012). Each sample was oven-dried at $105^{\circ} \mathrm{C}$. Representative aliquots of each composite were obtained by coning and quartering the dried sediment and then wet-sieved through a $63 \mu \mathrm{m}$ non-contaminating nylon and clear plastic sieve to obtain representative subsamples for subsequent chemical analysis. A selected group of trace elements $(\mathrm{Ag}, \mathrm{Al}, \mathrm{Cd}, \mathrm{Co}$, $\mathrm{Cu}, \mathrm{Fe}, \mathrm{Pb}, \mathrm{Ti}$, and $\mathrm{Zn}$ ) were determined using AAS after a $\mathrm{HF} / \mathrm{HClO}_{4} /$ aqua regia digestion in teflon beakers at $200^{\circ} \mathrm{C}$. TOC was determined by combustion using a CarloErba $\mathrm{C} / \mathrm{N}$ analyzer.

\subsection{Results and discussion}

With the exception of $\mathrm{Cd}$, all the other constituents determined contained elevated individual as well as median levels that exceeded national baseline concentrations (Table 1; Horowitz and Stephens, 2008). Whilst the median concentration for $\mathrm{Cd}$ did not exceed national baseline levels, individual samples did.

Of particular interest to Fulton County was that whilst most of the samples contained elevated major and trace element, as well as TOC concentrations, the samples displaying the most elevated levels all clustered around one particular location in the watershed. That location is near the mouth of Utoy Creek where it discharges to the Chattahoochee River, and also is the site of a number of medium to light industries, including a galvanizing plant (Fig. 1). The survey also indicated that Utoy Creek is likely to display impaired dissolved concentrations for a number of constituents other than $\mathrm{Zn}$ (e.g., Cu, Co, TOC). Finally, based on this survey, potential new, long-term monitoring also sites were identified. 


\section{Utoy Creek data plots}
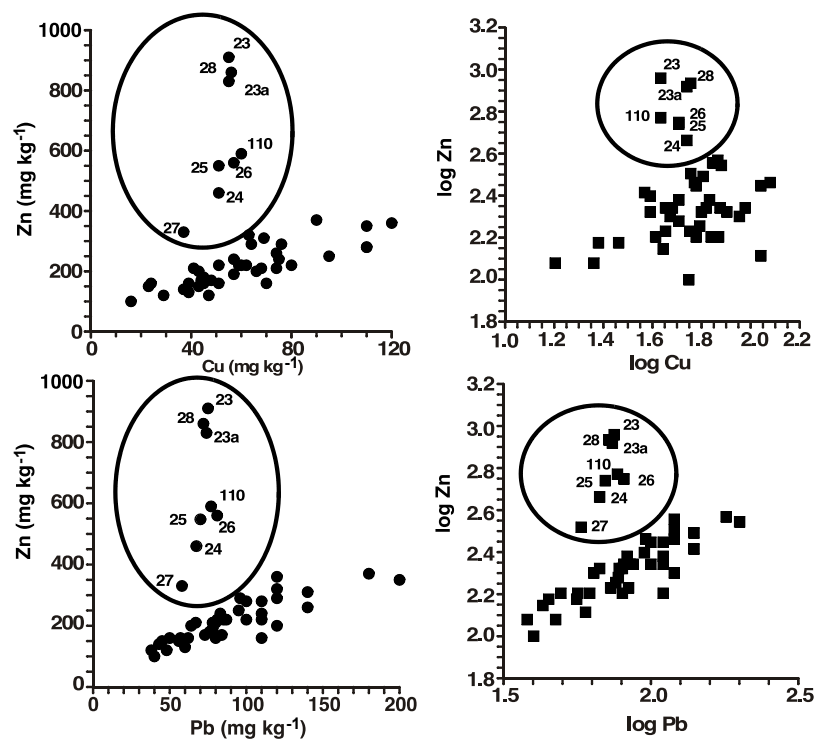

Figure 1. Plots of chemical data from the $<63 \mu \mathrm{m}$ fraction of bed sediments from Utoy Creek, Georgia, USA. There are similar plots for $\mathrm{Zn} / \mathrm{Fe}, \mathrm{Zn} / \mathrm{TOC}, \mathrm{Zn} / \mathrm{Al}$, and $\mathrm{Zn} / \mathrm{Co}$.

\section{Lake Coeur d'Alene, Idaho and the Spokane River}

Lake Coeur d'Alene (CDA) is a natural (submerged river bed) lake in the northern panhandle of Idaho that formed from the outwash from Lake Missoula during the last interglacial (e.g., Hobbs et al., 1965). The lake lies between the Selkirk and the CDA Mountains and extends northward from the St. Joe River to the headwaters of the Spokane River near the city of CDA, Idaho (Meckel Engineering et al., 1983; Bender, 1991). The main body of the lake is about $3.2 \mathrm{~km}$ wide by $40 \mathrm{~km}$ long, and up to $150 \mathrm{~m}$ deep in the thalweg (Meckel Engineering et al., 1983). The Spokane River flows downstream from the lake, passes through a series of dams, and eventually discharges into the Columbia River, some $180 \mathrm{~km}$ downstream.

The South Fork of the CDA River drains a substantial part of the CDA mining district and the so-called "Silver Valley". The mining district has been in operation since the 1880's and was one of the major sources of $\mathrm{Ag}, \mathrm{Pb}$, and $\mathrm{Zn}$ in the US (e.g., Bender, 1991). Most of the mining and ore-processing wastes were discharged directly into the South Fork of the CDA River (e.g., Horowitz et al., 1993). As late as 1964, estimates indicated that some 2200 tonnes/day of mining and processing wastes still were entering the South Fork (Reece et al., 1978). It also has been estimated that during the course of mining, processing, and smelting operations in the area, some 115 million tonnes of mine tailings were produced and that over $60 \%$ of this material probably entered the South Fork and the CDA River system (Javorka, 1991). These materials were highly enriched in $\mathrm{Ag}, \mathrm{As}, \mathrm{Cd}, \mathrm{Cu}, \mathrm{Fe}, \mathrm{Hg}, \mathrm{Mn}$,
Core SRC 1 - Upper-Mid Long Lake

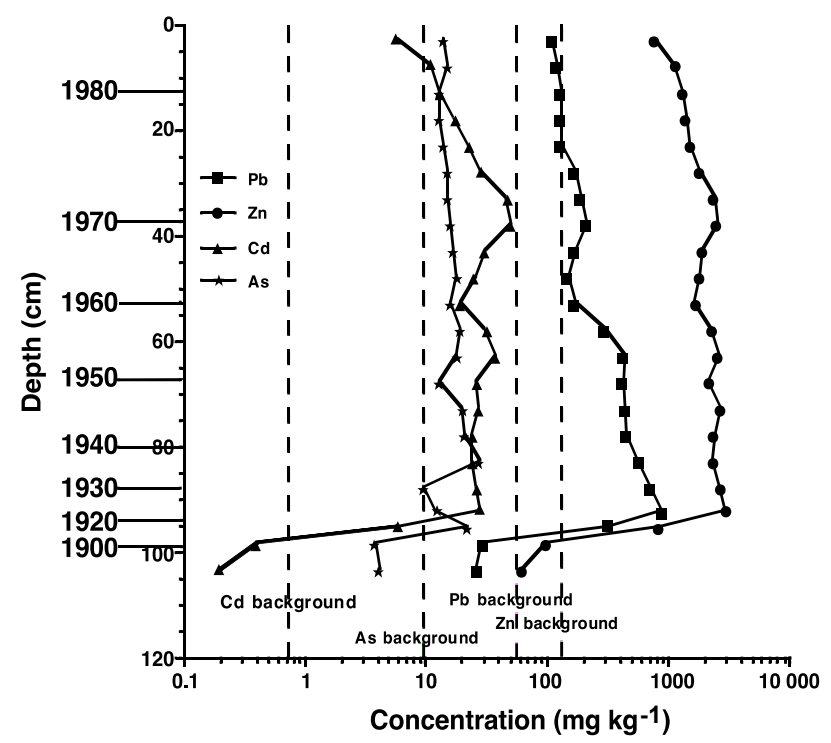

Core SRC 5 - Spokane River arm of Lake Roosevelt

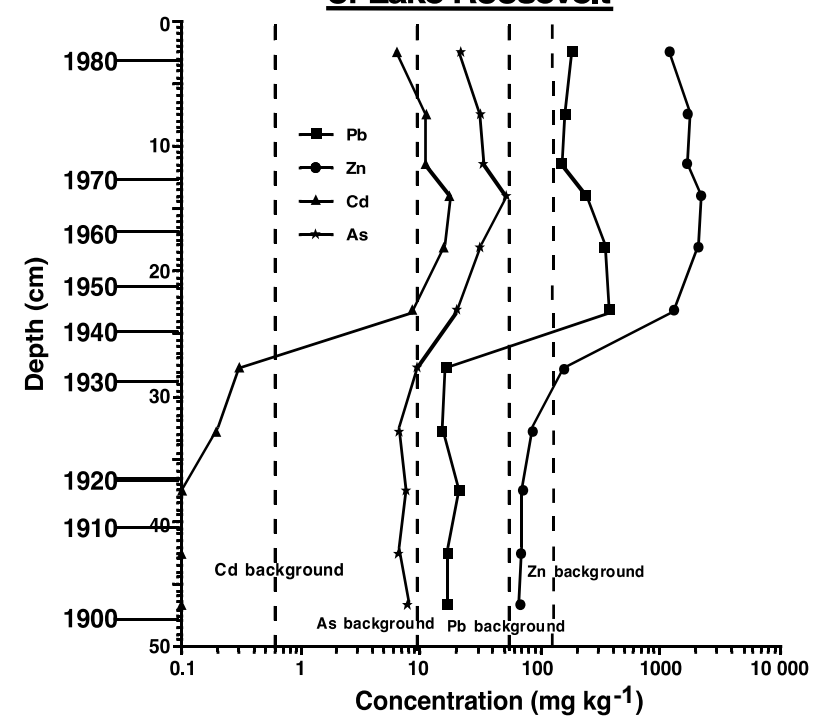

Figure 2. Plots of chemical data from two sediment cores collected in impoundments along the Spokane River, Washington, USA.

$\mathrm{Pb}, \mathrm{Sb}$, and $\mathrm{Zn}$ (Rabe and Bauer, 1977; Bender, 1991). In 1968, tailings ponds were established to limit sediment dispersion and downstream transport (Horowitz et al., 1993). A series of studies conducted between 1989 and 1999 indicated that Lake CDA contained some 75 million tonnes of trace element rich sediment, and that elevated sediment-associated constituents could be traced all the way to the Columbia River in the state of Washington (e.g., Horowitz et al., 1993, 1995; Grosbois et al., 2001).

The local mining companies, as well as the Northwest Mining Association, contended that the majority of the im- 
pacted sediment resulted from natural weathering processes associated with exposed segments of the ore body. To address this issue, a series of gravity cores were collected in Lake CDA and in the Spokane River system (Horowitz et al., 1995; Grosbois et al., 2001). The analytical data from the cores, in conjunction with absolute age dating based on ${ }^{137} \mathrm{Cs}$ and ${ }^{210} \mathrm{~Pb}_{\mathrm{ex}}$, clearly indicates that the onset of sedimentassociated trace element enrichment in Lake CDA and in the Spokane River began somewhere around $1910 \pm 20$ years, which is roughly contemporaneous with the onset of mining and smelting operations in the region (Fig. 2). Note that the onset of sediment associated-trace element enrichment of the most downstream core that was collected in the Spokane River arm of Lake Roosevelt began around 1930 (Fig. 2; Grosbois et al., 2001). That is contemporaneous with the initial closing of the Grand Coulee Dam, downstream from the Spokane River, on the Columbia River that also caused the formation of Lake Roosevelt and the Spokane River arm (e.g., Grosbois et al., 2001). Also note that the sediment-associated trace element concentrations, at least in the Spokane River, began to decline around 1970; that is contemporaneous with the construction of the tailings ponds along the South Fork of the CDA River. This would indicate that bed sediment chemistry does appear to respond fairly quickly to land use changes and or remediation measures. The CDA ore body has been dated as Proterozoic ( $>500$ million years BP; Hobbs et al., 1965), whereas Lake CDA has been dated as forming some 14000 years BP (Wyman, 1993); as a result, it is highly unlikely that the vast majority of the trace element-rich sediments in Lake CDA, and in the Spokane River system, resulted from natural weathering processes.

\section{The U.S. National Coastal River Survey}

Between 2010 and 2011, the U.S. Geological Survey (USGS) carried out a bed sediment-associated chemical survey using material collected at or near the mouths of 132 coastal rivers in the US. The primary objective of the study was to use the chemical data generated from the samples to develop firstorder approximations of the chemical fluxes emanating from the US to the coastal zone (Horowitz et al., 2012). The methods employed were essentially the same as those used in the Utoy Creek survey described earlier.

The basic premise of the study is that the chemical analyses of the $<63 \mu \mathrm{m}$ fraction of the upper $1 \mathrm{~cm}$ of riverbed sediments can serve as a surrogate for the average chemical composition of recent suspended sediments transiting each site. To evaluate the validity of that premise, minimum, maximum, and median suspended sediment-associated chemical concentrations determined between 1994 and 2006, as part of the revised NASQAN Program, determined for separated suspended sediment and analyzed utilizing the same procedures used in this study (Horowitz et al., 2001a, b), were compared with the chemical concentrations generated from the $<63 \mu \mathrm{m}$ fraction of the collected coastal river samples (Table 2; Horowitz et al., 2012). Based on that comparison, it appears that the premise is valid for the majority of the trace/major elements determined in the study. On the other hand, the data for carbon (TOC and TC), nitrogen (TN), and phosphorus (TP) are more ambiguous (Table 2). The bed sediment values for these constituents tend to fall either just below or just within the minimum levels for suspended sediment. This difference may be a reflection of the relatively small number of samples available for the comparison (especially for TN, and the Mississippi River Basin sites). However, the difference also may be the result of chemi$\mathrm{cal} /$ biological post-depositional remobilization that could reduce bed sediment-associated nutrient concentrations. As a result, regardless of the cause, the carbon and nutrient concentrations/annual fluxes determined from the $<63 \mu \mathrm{m}$ fraction of the bed sediments collected and analyzed during this study should be viewed as minimums.

\section{Conclusions}

Based on the three studies cited, it is possible to draw some conclusions about the efficacy of using bed sedimentassociated major/trace element and nutrient concentrations in water quality studies and monitoring programs. It does appear as if bed sediment chemical data, particularly that generated from the $<63 \mu \mathrm{m}$ fraction of the upper $1 \mathrm{~cm}$, can be used for a variety of water quality studies and monitoring programs provided that short term variations and/or temporal immediacy are not of primary concern, e.g.: for reconnaissance surveys to identify potential monitoring sites and/or "hotspots" (Utoy Creek); to establish historical reconstructions of the water quality/geochemical history of an area (Lake CDA and the Spokane River); and as surrogates for determining the mean/median concentrations of suspended sediment-associated trace/major elements and nutrients (National Coastal Survey). In the latter case, bed sedimentsurrogates may provide a means of establishing long termtrends that could be associated with decadal-long processes such as climate change, without having to resort to much more resource intensive intra- and interannual sampling and analysis programs.

Data availability. Individual data are available from the author(s) on request.

Competing interests. The authors declare that they have no conflict of interest. 


\begin{tabular}{|c|c|c|c|c|c|c|c|c|}
\hline Z & & 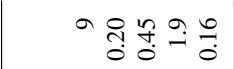 & 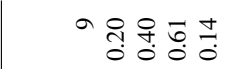 & 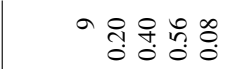 & 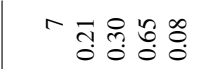 & N & 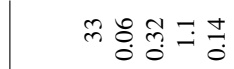 & \\
\hline$\circlearrowright$ & & $\sigma g \stackrel{i}{\rightarrow} \cong \stackrel{\infty}{=}$ & $a \underset{i}{a} \underset{i}{\infty} \simeq$ & $a \stackrel{\circ}{\circ} \underset{\dot{m}}{\circ}=\exists$ & $\ddot{m} \vec{m} \dot{\vec{n}} \hat{\sigma} \dot{m}$ & $\pm g \hat{\sigma} g \vec{i} \dot{m}$ & ద̊ & \\
\hline ¿ & $\widehat{\varrho}$ & ○ & 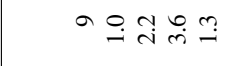 & a & 芯 & 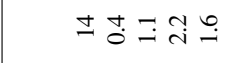 & कำ & \\
\hline$F$ & & a ఝ & 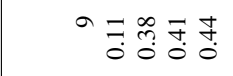 & 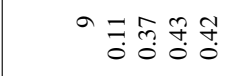 & 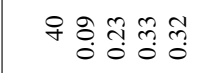 & ฟ & 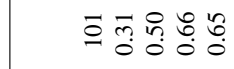 & \\
\hline ง & & 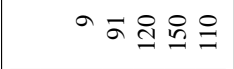 & a文弪织 & a in đి & 守守号号 & ते ले तृ & 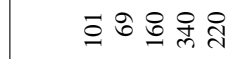 & \\
\hline$>$ & & の ळळळ & の乩@ぇ & の的品界 & チลタター & 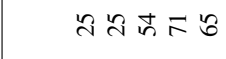 & 호응ㅇㅁㅇ & \\
\hline is & & 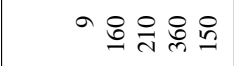 & a昌道年昌 & 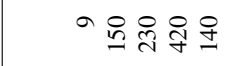 & 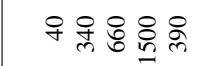 & 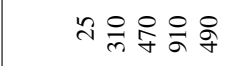 & 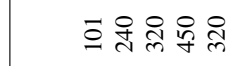 & \\
\hline$\stackrel{\infty}{<}$ & & - $\tilde{o}_{\mathrm{v}} \mathbb{z} \hat{0} \stackrel{n}{0}$ & 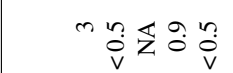 & 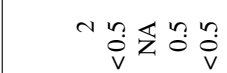 & 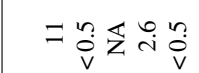 & 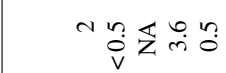 & 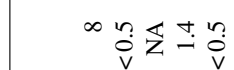 & \\
\hline 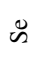 & & å & 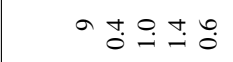 & 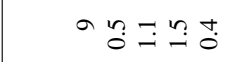 & 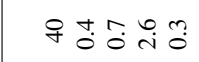 & चुत & ఏேすずす & 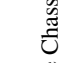 \\
\hline$\hat{F}$ & 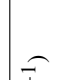 & のః & ๑ & のঃ̊ & f \& & 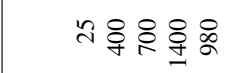 & 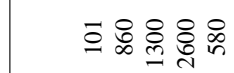 & \\
\hline $\bar{z}$ & $\frac{\infty 0}{60}$ & 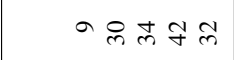 & $a m$ 电孚 & $a \pm m g t$ & $\bar{m} \simeq \widetilde{N}_{\infty}^{\infty} \stackrel{\infty}{-}$ & 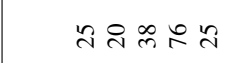 & 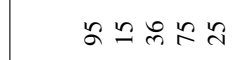 & \\
\hline$\stackrel{\circ}{\Sigma}$ & & $\operatorname{ard} n \pi$ & $a-N m-$ & $a-N m-$ & $r a m^{-}$ & $-\infty \infty=N$ & $\bar{m}-N \stackrel{d}{ } \vec{v}$ & \\
\hline I0 & & 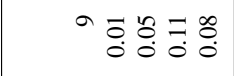 & r & 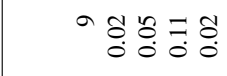 & 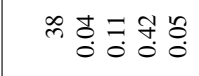 & 잉 & ๙ & 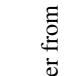 \\
\hline$\Sigma$ & & a \& & 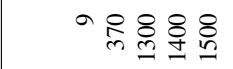 & a \& 8 & 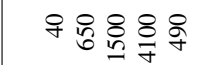 & 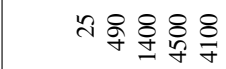 & 드욤응 $\frac{8}{2}$ & \\
\hline$\exists$ & & aț & 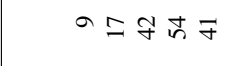 & $a \propto q \wp$ & 舟 & 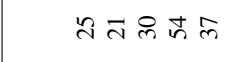 & 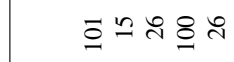 & \\
\hline 2 & & $\sigma \leadsto \dot{\sim} \bar{m}$ & ard d & arสีลิ & 우은모은 & 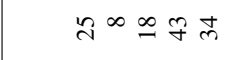 & 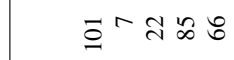 & \\
\hline 足 & & 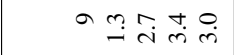 & $a=$ तु के ले & 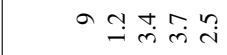 & q Oे $\hat{i} \stackrel{\infty}{i} \hat{i}$ & $\ddot{n}=\stackrel{0}{i} \dot{i} \dot{m}$ & 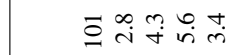 & \\
\hline u & & $\sigma \vec{\sim} \dot{\sim} \tilde{\lambda}$ & 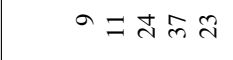 & $a=\tilde{\lambda} \dot{m}$ & $q^{\infty} こ コ さ$ & $\stackrel{\sim}{\sim} \infty \bigcup \exists \stackrel{\infty}{m}$ & 可芯品号字 & \\
\hline 8 & & 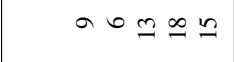 & $a+ \pm \simeq$ & $a+ \pm こ=$ & $q m r m \infty$ & $\ddot{n} m \infty \simeq$ & 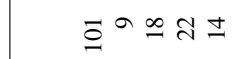 & \\
\hline U & & の묘요 & ดேีละ์ & 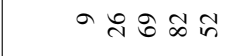 & ले & 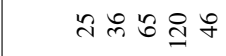 & 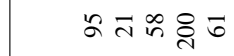 & \\
\hline$\tilde{J}$ & $\tau_{00}$ & ดทํㅇำ & am n? & $a m: t: 00 ?$ & 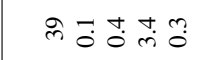 & $\bar{\top} \bar{O}$ & ลำํํㅇํำ & \\
\hline 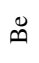 & 总 & $a \stackrel{\infty}{0}=\vec{i}$ & 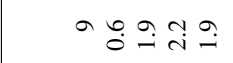 & a) & mి & 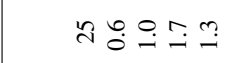 & 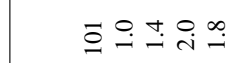 & \\
\hline$\tilde{\oplus}$ & & a요 윰 ్ㅠ & 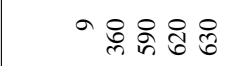 & 요요 & q & 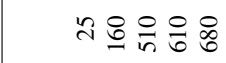 & 홍요 운응영 & 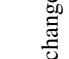 \\
\hline$<$ & & $\sin ^{\circ}{ }^{n}=$ & $\sigma_{\ngtr} \cong \simeq \subseteq$ & $\sigma r= \pm \bar{\infty}$ & 웃으늠 & 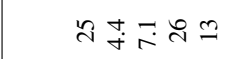 & 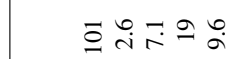 & \\
\hline क & & $a \stackrel{0}{0} \stackrel{\infty}{0} \stackrel{\circ}{0} \stackrel{\infty}{0}$ & 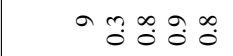 & $a \stackrel{\infty}{0} \stackrel{\infty}{0} \stackrel{\infty}{0} \tilde{0}$ & q $\stackrel{0}{0} \stackrel{\infty}{-\infty} \underset{0}{0}$ & ํํำ & 통ㅇㅇ & \\
\hline « & 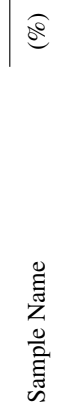 & 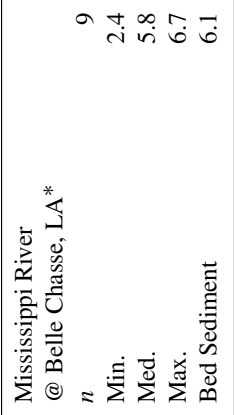 & 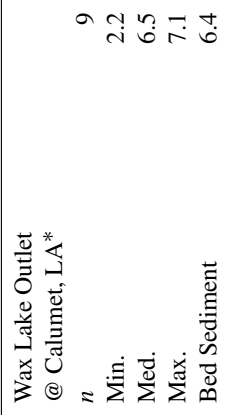 & 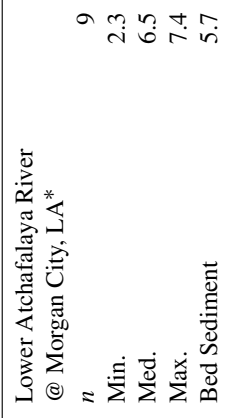 & 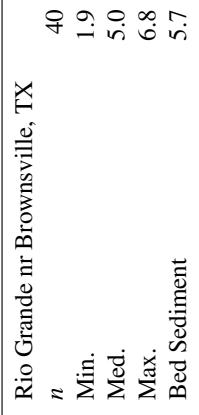 & 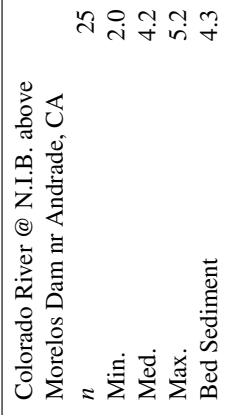 & 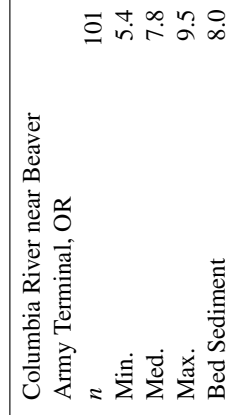 & 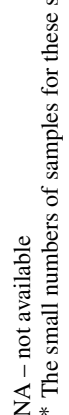 \\
\hline
\end{tabular}




\section{References}

American Public Health Association (APHA): Standard Methods for the Examination of Water and Wastewater, 22nd edn., American Public Health Association: Washington, D.C. 2012, 3-6-3-7, 3-1-4-194, 3-9, 4-135-4-137, 4-107-4-108, 2012.

ASTM: Annual Book of ASTM Standards, Section 11, 11.01, Water and Environmental Technology, ASTM: West Conshohocken, Pennsylvania, 1505 pp., 2011a.

ASTM: Annual Book of ASTM Standards, Section 11, 11.02, Water and Environmental Technology, ASTM: West Conshohocken, Pennsylvania, 1507 pp., 2011 b.

Bender, S.: Investigation of the chemical composition and distribution of mining wastes in Killarney Lake, Coeur d'Alene Area, northern Idaho, Unpublished MS Thesis, University of Idaho, Moscow, Idaho, 98 pp., 1991.

Fauth, H., Hindel, R., Siewers, U., and Zinner, J.: Geochemischer Atlas Bundesrepublik Deutschland, BGR Hannover: Schweizerbart'sche Verlagsbuchhandlung, Stuttgart, 79 pp., 1985.

Gray, J. E., Van Metre, P. C., Pribil, M. J., and Horowitz, A. J.: Tracing historical trends of $\mathrm{Hg}$ in the Mississippi River using $\mathrm{Hg}$ concentrations and $\mathrm{Hg}$ isotopic compositions in a lake sediment core, Lake Whittington, Mississippi, USA, Chem. Geol., 395, 80-87, 2015.

Grosbois, C., Horowitz, A. J., Smith, J. J., and Elrick, K. A.: The Effect of Mining and Related Activities on the Sediment-Trace Element Geochemistry of Lake Coeur d'Alene, Idaho, USA. Part III. Downstream Effects: The Spokane River Basin, Hydrol. Process., 15, 855-875, 2001.

Gustavsson, N., Bolviken, B., Smith, D., and Severson, R.: Geochemical landscapes of the conterminous United States - New map presentations for 22 elements, U.S. Geological Survey Professional Paper 1648, Denver, 38 pp., 2001.

Hawkes, H. and Webb, J.: Geochemistry in Mineral Exploration, Harper \& Row, New York, 415 pp., 1962.

Hobbs, S. W., Griggs, A. B., Wallace, R. E., and Campbell, A. B.: Geology of the Coeur d'Alene District, Shoshone County, Idaho, U.S. Geological Survey Professional Paper 478, 139 pp., 1965.

Horowitz, A., Elrick, K., and Smith, J.: Annual suspended sediment and trace element fluxes in the Mississippi, Columbia, Colorado, and Rio Grande drainage basins, Hydrol. Process., 15, 11691207, 2001a.

Horowitz, A. and Stephens, V.: The effects of land use on fluvial sediment chemistry for the conterminous U.S. - Results from the first cycle of the NAWQA Program: Trace and major elements, phosphorus, carbon, and sulfur, Sci. Total Environ., 400, 290314, 2008.

Horowitz, A., Elrick, K., and Smith, J.: Estimating suspended sediment and trace element fluxes in large river basins: Methodological considerations as applied to the NASQAN Program, Hydrol. Process., 15, 1107-1132, 2001b.

Horowitz, A. J.: Monitoring suspended sediments and associated chemical constituents in urban environments: Lessons from the City of Atlanta, Georgia, USA water quality monitoring program, J. Soil. Sediments, 9, 342-363, 2009.

Horowitz, A. J.: A Review of Selected Inorganic Water QualityMonitoring Practices: Are We Really Measuring What We Think, And If So, Are We Doing It Right?, Environmental Science and Technology, 47, 2472-2486, 2013.
Horowitz, A. J. and Hughes, W. B.: The U.S. Geological Survey and City of Atlanta Water-Quality and Water-Quantity Monitoring Network, U.S. Geological Survey Fact Sheet 2005-3126, 4 pp., 2006.

Horowitz, A. J., Elrick, K. A., and Callender, E.: The effect of mining on the sediment-trace element geochemistry of cores from the Cheyenne River Arm of Lake Oahe, South Dakota, USA, Chem. Geol., 67, 17-33, 1988.

Horowitz, A. J., Elrick, K. A., and Cook, R. B.: The effect of mining and related activities on the sediment-trace element geochemistry of Lake Coeur d'Alene, Idaho, USA - Part I: Surface Sediments, Hydrol. Process., 7, 403-423, 1993.

Horowitz, A. J., Elrick, K. A., Robbins, J. A., and Cook, R. B.: The effect of mining and related activities on the sediment-trace element geochemistry of Lake Coeur d'Alene, Idaho, USA - Part II: Subsurface Sediments, Hydrol. Process., 9, 35-54, 1995.

Horowitz, A. J., Meybeck, M., Idlafkih, Z., and Biger, E.: Variations in trace element geochemistry in the Seine River Basin based on floodplain deposits and bed sediments, Hydrol. Process., 13, 1329-1340, 1999.

Horowitz, A. J., Stephens, V., Elrick, K., and Smith, J.: Concentrations and annual fluxes of sediment-associated chemical constituents from conterminous U.S. coastal rivers using bed sediment data, Hydrol. Process., 26, 1090-1114, 2012.

Horowitz, A. J., Elrick, K. A., Smith, J. J., and Stephens, V. C.: The Effects of Hurricane Irene and Tropical Storm Lee on the Bed Sediment Geochemistry of U.S. Atlantic Coastal Rivers, Hydrol. Process., 28, 1250-1259, 2014.

Javorka, E.: Lake water quality assessment Coeur d'Alene Lake, Benewah and Kootenai Counties, Idaho. Coeur d'Alene Basin Interagency Group, Coeur d'Alene Tribe of Idaho, Coeur d'Alene Subagency, Plummer, Idaho, 42 pp., 1991.

Meckel Engineering, Brown, and Caldwell Consulting Engineers: Kootenai County lakes master plan, Meckel Engineering/Brown and Caldwell, Coeur d'Alene, Idaho, 1-30-1-35, 2-24-2-32, 1983.

Otteson, R., Bogen, J., Bolviken, B., Volden, T., and Haugland, T.: Geochemical Atlas of Norway - Part 1: Chemical Composition of Overbank Sediments, Norwegian Geological Survey, Trondheim, 140 pp., 2000.

Rabe, F. and Bauer, S.: Heavy metals in lakes of the Coeur d'Alene River valley, Northwest Science, 51, 183-197, 1977.

Reece, D., Felkey, J., and Wai, C.: Heavy metal pollution in the sediments of the Coeur d'Alene River, Idaho, Environ. Geol., 2, 289-293, 1978.

U.S. Geological Survey (USGS): National field manual for the collection of water-quality data, U.S. Geological Survey Techniques of Water-Resources Investigations, Book 9, Chaps. A1A5, available at: http://pubs.water.usgs.gov/twri9A, last access: 31 December 2016.

Van Metre, P. C. and Horowitz, A. J.: An 80-year Record of Sediment Quality in the Lower Mississippi River, Hydrol. Process., 27, 2438-2448, 2013.

Van Metre, P. C., Horowitz, A. J., Mahler, B. J., Foreman, W. T., Fuller, C. C., Burkhardt, M. R., Elrick, K. A., Furlong, E. T., Skrobialowski, S. C., Smith, J. J., Wilson, J. T., and Zaugg, S. D.: Effects of Hurricanes Katrina and Rita on the Chemistry of Bottom Sediments in Lake Ponchartrain, Louisiana, USA, Environ. Sci. Technol., 40, 6894-6902, 2006. 
Webb, J., Thornton, I., Thompson, M., Howarth, R., and Lowenstein, P.: The Wolfson Geochemical Atlas of England and Wales, Oxford University Press, Oxford, 70 pp., 1978.

West Atlanta Watershed Alliance: Utoy Creek, http://wawa-online. org/our-watershed/greenspaces/utoy-creek/, last access: 25 October 2016.
Wyman, S.: The potential for heavy metal migration from sediments from Lake Coeur d'Alene in the Rathdrum Prairie Aquifer, Kootenai County, Idaho. Idaho Water Resources Research Institute, Research Technical Completion Report, University of Idaho, Moscow Idaho, 12-18, 1993. 